'SAY NO TO THE ATO': 'THE CULTURAL POLITICS OF PROTEST AGAINST

THE AUSTRALIAN TAX OFFICE

Kersty Hobson

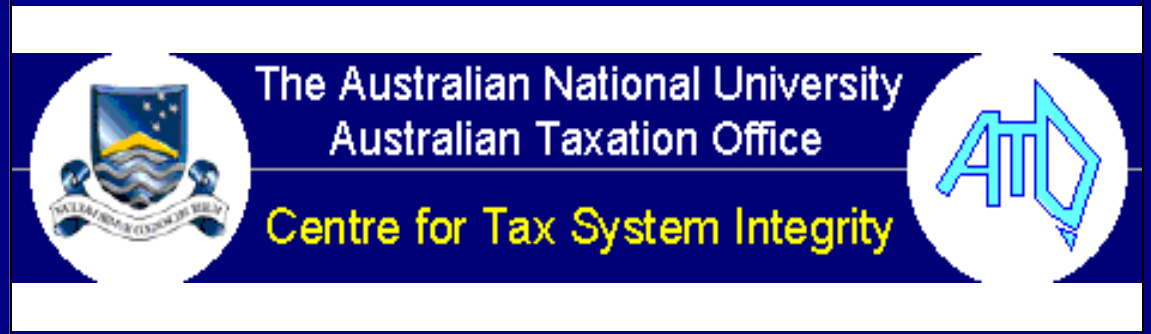

WORKING PAPER No 37

December 2002 


\title{
'SAY NO TO THE ATO': THE CULTURAL POLITICS OF PROTEST AGAINST THE AUSTRALIAN TAX OFFICE
}

Kersty Hobson

\author{
Centre for Tax System Integrity \\ Research School of Social Sciences \\ Australian National University \\ Canberra, ACT, 0200
}

ISBN 0642768366

ISSN 1444-8211

\section{WORKING PAPER No 37}

December 2002 
(C) Centre for Tax System Integrity, Research School of Social Sciences, Australian National University 2002

(C) Commonwealth of Australia 2002

National Library of Australia

Cataloguing-in-Publication data:

Hobson, Kersty, 1971-.

'Say no to the ATO': The cultural politics of protest against the Australian Tax Office.

Bibliography.

ISBN 0642768366.

1. Australian Taxation Office - Public opinion.

2. Taxpayer compliance - Australia. 3. Tax evasion -

Australia. 4. Investments - Taxation - Australia.

I. Centre for Tax System Integrity. II. Title. (Series:

Working paper (Centre for Tax System Integrity); no. 37).

336.2910994

If you would like to make any comments on this working paper please contact the author directly within 90 days of publication.

\section{Disclaimer}

This article has been written as part of a series of publications issued from the Centre for Tax System Integrity. The views contained in this article are representative of the author only. The publishing of this article does not constitute an endorsement of or any other expression of opinion by the Australian National University or the Commissioner of Taxation of the author's opinion. The Australian National University and the Commissioner of Taxation do not accept any loss, damage or injury howsoever arising that may result from this article. This article does not constitute a public or private ruling within the meaning of the Taxation Administration Act 1953, nor is it an advance opinion of the Commissioner of Taxation. 


\section{THE CENTRE FOR TAX SYSTEM INTEGRITY WORKING PAPERS}

The Centre for Tax System Integrity (CTSI) is a specialised research unit set up as a partnership between the Australian National University (ANU) and the Australian Taxation Office (Tax Office) to extend our understanding of how and why cooperation and contestation occur within the tax system.

This series of working papers is designed to bring the research of the Centre for Tax System Integrity to as wide an audience as possible and to promote discussion among researchers, academics and practitioners both nationally and internationally on taxation compliance.

The working papers are selected with three criteria in mind: (1) to share knowledge, experience and preliminary findings from research projects; (2) to provide an outlet for policy focused research and discussion papers; and (3) to give ready access to previews of papers destined for publication in academic journals, edited collections, or research monographs. 


\begin{abstract}
This paper examines taxpayers' protests against amended assessments received from the Australian Taxation Office (Tax Office), prompted by their involvement in tax effective schemes. Considering this issue through 'social movement' literature, and focussing on the Goldfields region of Western Australia, it aims to explore why some individuals became involved in schemes and why they later felt justified in protesting publicly against the Tax Office. It does not aim to access the 'truth' of claims by investors that they merely wanted to secure their financial future through legitimate investments, versus other's claims they were knowingly practicing tax avoidance. Nor does it aim to make judgments on who is 'right' or 'wrong'. Instead it considers the 'stories' that are motivating protestors' actions now. These stories are important, as they are the moral foundations for subsequent and ongoing protests. They also help to understand the ways in which this issue has impacted individuals and communities 'culturally', beyond the obvious financial and legal issues.
\end{abstract}

The main findings are that investors feel their personal and collective identity has been severely infringed by amended assessments. Protests are not just about money but are fundamentally moral claims over their rights and roles as 'honest' Australian citizens. Social movement literature helps to show how these moral claims are not experienced as separate from protestors' financial, self-interested concerns. Rather, they are 'read through the lens' of culture and emotion, providing a 'moral shock' to investors' identity and feelings of security.

These findings have implications for governance in Australia. For one, government agencies have in recent times been keen to incorporate the language of fairness and openness into their ambits. However, being seen to then be institutionally inflexible and without a 'human face' when dealing with citizens - a point expressed continually by investors in this case study - can prove hugely damaging in the long term. It may be too late to re-engage these investors into a culture of voluntary compliance. However, being aware of the potential impact that administrative and legal decisions can have on citizens beyond the realms of finance could prove a first step in enabling the reflexive and responsive institutions, which citizens have come to hope for, and even expect, in contemporary Australia. 


\section{'Say no to the ATO': The cultural politics of protest against the Australian Tax Office $^{1}$}

Kersty Hobson

\section{Introduction: The rise of tax effective schemes and investors' protests}

During the 1980s and 1990s, the Tax Office became increasingly concerned about 'aggressive tax planning' practices, wherein accountants and clients search for legal often marginally so - ways of minimising tax. Although such practices have a long history, their availability was seemingly growing in terms of number of schemes available. They were also spreading geographically, moving from urban to suburban and rural areas; and socially, from high income to middle income individuals.

One such set of practices is 'tax-effective investment schemes' ('schemes' herein), defined as any arrangement that is entered into by a taxpayer in order to obtain a tax benefit. These can include 'round-robin schemes', including complex non-recourse financing of agriculture, afforestation and franchise schemes. During the 1990s, scheme deductions claimed by Australian taxpayers grew from \$A176 million in 1994 to over \$A1 billion in 1997 (Laurence, 9 March 2001). By 2002, it was calculated there were about 40000 investors involved in over 160 schemes across Australia (Buffini, 2002).

Alerted to the growth in deductions being claimed the Tax Office examined the financing arrangements of schemes. They ruled that some scheme involvement amounted to tax avoidance, thus contravening Australian Tax Law. As a result, all deductions previously claimed for participation in the disputed schemes plus between $5 \%$ and $50 \%$ penalty and $13.86 \%$ interest were claimed by the Tax Office. This process began in 1998 and took the form of issuing involved taxpayers with amended assessments (Senate Economics References Committee, 2000; attachment A). Individual assessments range from \$20 000 to over $\$ 200000$, with an average of $\$ 75000$ (Senate Economics References Committee, 2001b), allegedly totalling an estimated \$A4.3 billion in deductions claimed.

\footnotetext{
${ }^{1}$ The present paper was written at the end of 2001 reflecting the scheme situation at that time.
} 


\section{Protests against amended assessments and the Tax Office}

In reaction, some affected taxpayers have been vocal in protests against their assessments and the Tax Office. They argue that schemes were sold to them by independent promoters and marketed as legal means of investment, thoroughly endorsed by various institutional authorities (see below for further discussion). Whereas the Tax Office are within their legal ambit to take such action and impose these levels of fines, some investors feel the treatment is harsh, financially untenable and contrary to a spirit of fairness that stateindividual relations should adhere to. As a result, many have utilised bureaucratically endorsed channels of appeal to object to the situation (for example, ATO internal appeal system, the Taxation Ombudsman). Some have also been publicly protesting in attempts to get their tax debts and their reputations cleared. The ultimate aim of these protests is to persuade the Tax Office to draw a 'line in the sand' (that is, cancel all affected assessments).

Although exact figures are sketchy, it appears that the majority of investors have so far not settled with the Tax Office. For some, this is because they cannot afford to or have been told by their legal and/or financial advisers to wait until relevant court judgments are known. However, others have no intention of paying their bills, saying they will not pay the Tax Office a 'red cent'. Indeed, the issue has remained in somewhat of a deadlock since late 2000, with many of the Tax Office's subsequent concessions to investors falling on deaf ears ${ }^{2}$.

\footnotetext{
${ }^{2}$ For example, in April 2001, the Tax Office offered some scheme investors a reduction of interest on their assessments, from 13.86 to $4.72 \%$. In return, they did not have to disclaim any future legal action against the Tax Office, they just had to enter into a payment arrangement (see Senate Economics References Committee (2001a) - Inquiry into Mass Marketed Tax Effective Schemes and Investor Protection: Interim Report, Parliament of the Commonwealth of Australia). Few took up the offer. To follow, on 14 February 2002 the Tax Office announced a compromise settlement for investors. This consisted of all penalties and interest being removed from amended assessments, as well as investors being allowed to keep or claim deductions for any cash personally paid into the schemes. By December 2002, $87 \%$ of the investors had settled.
} 
Along with refusals to pay, an informal protest network of affected investors has emerged, which has been responsible for organising public marches, meetings, and stoking media interest in the issue. One geographical focus of both payment-refusals and overt protests is the Goldfields region of Western Australia, especially the city of Kalgoorlie-Boulder. Although protests in this region are nothing new, this issue has caused great institutional consternation and public interest, taking politicians, the Tax Office and the Australian media by surprise. As the Australian Taxation Ombudsman has dryly put it:

'... the ATO had not given any real consideration to how these taxpayers might respond to the ATO's proposed amendment action or the likely impact this would have on ATO operations' (Commonwealth Ombudsman, 2001, p. 25).

As a result, the Tax Office is sponsoring court cases in relation to schemes in attempts to set legal precedence ${ }^{3}$. Indeed, throughout the rulings and protests, the Tax Office has maintained its line that this is an issue of tax law that is resolvable through judicial channels.

\section{Structure of paper}

The remainder of this paper is structured as follows. A brief theoretical discussion examines how 'social movement' literature can help understand the collective and personal reasons for protests against the Tax Office. Then, the research aims and methods used in this paper are discussed. The context for this research is then outlined by examining key economic and geographical features of the Goldfields region, and some characteristics of the protests to emerge from the region. This is followed by considering why individuals became involved in schemes, focussing on their 'stories of justification'. These stories lay the foundation for discussing why Goldfields residents felt compelled to publicly defy the Tax Office, in terms of its assault to their individual, collective and regional identity. The reasons why this happened in the Goldfields as opposed to elsewhere in Australia are then

\footnotetext{
${ }^{3}$ On Friday 15 March 2002 the Federal Court returned the judgment that the Tax Office was correct in ruling involvement in the Budplan scheme contravened Australian Tax Law (Buffini \& Fabro, 2002). Other court cases are on-going.
} 
discussed. The concluding sections consider the implications of this research for issues of governance and tax administration in Australia.

\section{Theoretical premise: Social movements and citizenship protest}

This paper considers investors' refusals to pay and their protests against the Tax Office from the perspective of 'social movement' literature. This literature is concerned with why and how individuals become involved in forms of collective and sustained social protest. Its usefulness in this case study is its ability to connect individual motivations and concerns, and the stories they tell about their lives and actions, with broader social issues and changes (for a social psychological analysis of this case study, see Murphy, 2002). This is important, as understanding protest necessitates not only consideration of social and structural factors but also the 'moral sensibilities and convictions' of individuals (Jasper, 1997, p. 5 \& p. 11).

As such, it is argued here that investors' protests signal the articulation of a 'moral sensibility and conviction' through being an unusual form of protest on two fronts. First, the background hum of low-level citizen non-compliance, a seemingly intractable part of any tax regime (Braithwaite, forthcoming) has been turned up to full volume. Second, many new forms of protest belong to what researchers call 'new social movements'. These are protests that concern lifestyle or 'post-material' issues, such as animal and gender rights. Investors' protests appear different from these new social movements, pertaining instead to economic and distributive issues. This last point is important as it enables us to ask an integral question - if protests do not concern usual subjects of new social movements, what are they about?

\section{Understanding social protest: putting citizen concerns back into economic protest}

Scheme investors' protests without doubt have financial and material foundations. These are often discussed in social movement literature as theories of 'resource mobilisation'. This is a rational-actor or economic-actor perspective that considers the potential gains or losses an individual faces through taking part in protest (Polletta \& Jasper, 2001). As such, 
it has relevance to this case study. Investors potentially have a great deal to lose if they comply with the Tax Office's wishes in the short term, that is, pay their bills (although in the long term this strategy may very well prove costly in light of the legal precedent set by the Budplan ruling).

However, this theory alone does not help understand protestors' actions completely, as protests also have strong moral and identity drivers. Although never directly called so by the Tax Office, investors feel the implication that they are 'tax cheats' assaults both their self-identity and their public persona. Therefore protests are about economy and identity at the same time. Indeed, a key point this paper aims to make is that these two drivers to action are often researched as if they are mutually exclusive; or that they matter at different times in a protest cycle; or that some individuals are concerned with money whilst others care about identity. Instead, the following discussion aims to show that Goldfields protests have both a moral identity and financial foundation, which occur simultaneously and are inseparable in the eyes and minds of protestors.

Indeed, the inclusiveness of the spheres of morality and the economy underpins these protests, possibly marking an emerging area of contestation in Australia. This is one where citizens do not read tax rulings simply as administrative decisions to be dealt with through bureaucratic procedures and deferred to through the rule of law. Rather, they are read as comments on and threats to individual and family identity, security and their social position as 'ordinary' Australians. Braithwaite (forthcoming) has aptly named this as marking a form of 'new defiance'. Here, citizens believe there should exist a form of social contract of care and mutual respect between state and taxpayer. In this research, investors believe this contract has been breached, making tax a site of 'cultural politics' (Nash, 2000, 2001), wherein identities and sites of power are re-drawn and contested.

This argument aims to build upon Melucci's (1989) discussions of the difference between citizenship and post-citizenship protests. Melucci's arguments run counter to the many researchers who suggest that citizenship struggles over basic social equality and the redistribution of social 'goods' have been eclipsed in countries like Australia by postcitizenship issues such as animal rights or lifestyles politics. Although movements that 
focus on these issues are indeed prevalent, Melucci argues that citizenship struggles are in fact alive and well, along with the on-going debates of what it means to be a 'citizen' today (for example, Hudson \& Kane, 2000). His point is that citizenship struggles have become less easily recognisable because their traditional forms have changed.

For example, conflicts over work rights were once geographically, issue and class specific (such as, strikes by dockworkers over pay and conditions, and protests at the start of the industrial revolution about the threats to labour posed by new technology). Now the dimensions of class, space and issues of public concern have been reshaped by multi-level social and labour changes. This makes protest diffuse and not easily placed within distinct spatial and social boundaries. As such, protests may concern specific 'interest' issues whilst simultaneously raising concerns what modern citizenship means today (Probyn, 1997, Yuval-Davis, 1999). Indeed, it is argued that at all protest foundation is the personal and collective need for a sense of 'ontological security' within contemporary conditions of flux and seeming instability (Turner, 2001).

This redrawing of the forms of protest is echoed throughout this case study, which, this paper argues, is fundamentally about being an Australian citizen today. For one, schemes have affected people all across Australia. Rural and urban dwellers from all walks of life and professions are arguing that their current and future livelihoods are now severely threatened. This has given rise to multiple sites and forms of protest, prompted by different actors throughout the on-going period of protest. As a result, protests are diffuse, multifaceted and touch upon an array of issues that stretch from immediate financial concerns to what now constitutes being a 'decent and honest' Australian.

\section{Research Aims and Methods}

Taxation is not just a fiscal issue. It also encompasses the social and moral spheres of equity, community, and governance (see Blumenthal et al., 2001, Braithwaite, forthcoming, Coleman \& Freeman, 1997), as well as being part of broader social institutions that help carve the 'cultural constructions of identity' (Taylor, 1998, p. 338). Understanding taxpayers' behaviour requires understanding their values, experiences, 
contexts and motives, as well as economic attitudes and circumstances. To this end, the Centre for Tax System Integrity at the Australian National University undertook research to investigate further why some Goldfield residents chose to take part in these schemes, and why they have refused to pay their amended assessments with such force, unity and conviction. The Goldfields was chosen as protestors were accessible, in terms of being willing to talk about their experiences, and also because of the intensity of protest to emerge from the area.

Qualitative research methods were used to draw an in-depth and contextual picture of events from the voices of the individuals affected. This research had several facets. First, available literature, press clippings, Internet sources and official reports were collected and analysed for content, to understand not only some of the central arguments but also to see how they were discursively constructed. Second, two researchers undertook fieldwork in the Goldfields region. Here, interviews were conducted with 29 investors, recruited through key community individuals, willing to share their contacts and networks. Interviews were semi-structured, wherein interviewees were asked to talk about their reasons for scheme involvements, their amended assessments, how they had responded to and feel about these events, and their possible futures. As well as scheme participants, three community workers who had not invested in schemes but have been central to subsequent protests were interviewed ${ }^{4}$. Also, whilst in the Goldfields further relevant local information was collected, and participant observation was possible through, for example, attending a public meeting about the schemes, hosted by Senator Shane Murphy and held in Kalgoorlie town hall on Tuesday 23 October 2001. In addition, a one-hour interview was carried out with three Tax Office staff in Canberra directly involved in the dealing with aggressive tax planning issues.

All interviews were taped and transcribed. Both sets of texts - documents and transcripts were analysed using open coding methods, to draw out both the main descriptive and analytical points (see Strauss, 1987), and the two researchers cross-referenced codes and

\footnotetext{
4 They were a local accountant, a coordinator of a community legal centre, and a mine manager from Kalgoorlie.
} 
analyses for validity and triangulation. The quotes in the remainder of the paper are drawn verbatim from the interviews although names have been deleted for reasons of confidentiality.

However, it is important here to draw attention to a couple of methodological caveats. First, this research was not aiming to secure a 'representative' sample of investors from whom generalisations can be drawn that can then be applied to thousands of other investors. Rather, the aim was to get an in-depth look at the contexts and processes taking place, which are generally not accessible through large-scale survey research. Or as Jasper (1997, p. 11) has put it: 'To understand why and how people protest, we need to know what they care about and how they see their place in the world'. It can be argued that the Goldfields is an aberration in terms of how other investors across Australia have reacted. The point to make is that this is the very reason why it is of research interest. Why have such strong feelings against the Tax Office been voiced in this area and what are the bases of these protests? These questions are important as sites of conflict and protest often can tell us a great deal about social changes taking place, as they represent openings or cleavages in social relations.

The second point to make is that this research cannot say anything about why others in the Goldfields did not invest in the schemes. For one, it is difficult to find out how many people were offered the schemes and turned them down in proportion to the number that invested, owing to the ad hoc and informal ways in which schemes were promoted. Theoretically, it was possible to 'ask around' whilst in the Goldfields, to try and talk to people who chose not to get involved. However, the sensitive and personal nature of the issue, and anger it evokes in some people made the researchers decide not to talk a great deal about their reasons for being in the Goldfields except to the pre-contacted interviewees. This is an acknowledged gap in this research and could possibly be redressed by asking interviewees if they knew of people in their networks who thought of investing and decided against it, and who would be willing to talk about it. 


\section{The Western Australian Goldfields: Setting the scene}

The Goldfields region in Western Australia was targeted strongly by promoters of schemes and thus, hard-hit by subsequent amended assessments. Located in outback (inland) Western Australia, the region has an estimated resident population of approximately 59000 , with the city of Kalgoorlie-Boulder housing the highest proportion at 32000 (see http://www.gedc.wa.gov.au/fr-populat.html). Aboriginal communities have historically occupied the area (for example, Christensen, 1979). In the late 1800s Irishman Paddy Hanlan found gold, heralding an influx of Anglo economic interest and people that continues today (see Blainey, 1993), which has displaced and marginalised the indigenous occupiers (Howitt, 1990). In general, the Goldfields today can be characterised as:

... isolated regional mining and pastoral centres with relatively small populations and hundreds of kilometres away from Perth. Geographically, the regions cover thousands of square kilometres and include small mining towns and camps, long established pastoral centres with perhaps only a few dozen inhabitants, and aboriginal communities with limited facilities and shifting populations. For the most part the environment is harsh and unforgiving with extremes of temperature. (Chidlow, 1998)

Mining, mostly of gold and nickel, is still central to the regional economy. This creates a profile of young and mobile workers who move to the area to take advantage of the reported high wages (for example, Patterson Market Research, 1999), estimated at about $157 \%$ the national average (see http://www.kalgoorliecci.asn.au/living).

However, this is not 'easy money'. High wages are earned by working 14-hour days underground, often 13 consecutive days out of 14. Mining remains a harsh and sometimes unsafe industry (for example, Nichols, 2001), that takes a toll on individual health and family life but which still draws a great deal of labour into the area (see Stimson, 2001). This all takes place in a region where living costs, especially food and fuel prices, are relatively high, and state and federal infrastructure and welfare investment is declining, a pattern similar elsewhere in rural Australia (for example, Panelli, 2001). In this context, some workers are paying the top tax bracket of 47 cents in the dollar, leaving many to feel 
that although on paper they appear well off, in reality their disposable income does not match the ardour and personal costs of their employment.

\section{Community reactions to amended assessments}

This combination of high wages, high taxes and a 'get in, get ahead and get out' approach of many working in the Goldfields made it a lucrative focus for the individuals marketing and selling schemes. As a result, nearly 1000 individuals in the Goldfields (half of these in Kalgoorlie-Boulder) are recorded by the Tax Office to be scheme participants and have received, or will receive, amended assessments.

Starting in late 1999 amended assessments started to arrive in Goldfield residents' letterboxes. As more and more people received letters, word spread informally through community and work networks about the number of people affected and the despair being felt. Community workers in Kalgoorlie-Boulder became concerned about the emotional impact this was having. As a result, a public meeting was organised in early 2001 and the Goldfields Legal Community Centre circulated a short questionnaire around KalgoorlieBoulder to gauge the number of people involved and their experiences to date. The 277 questionnaires returned showed great emotional distress and hardship being felt by investors and the families of amended assessment recipients (Harris et al., 2001).

However, private despair quickly turned into public outrage. During 2001, the region became a focus of protest against the Tax Office's actions. As well as public meetings and marches, other forms of protest emerged that were less geographically specific. These included the establishment of three 'fighting funds' that aimed to enable investors to collectively fight the Tax Office through the courts, open to all affected to join. Also, Internet discussion and resistance groups were set up that now involve scheme investors from all over Australia (for example, Project Tax Resolution Group http://groups.yahoo.com/group/australian-project-tax-resolution). Although the core group of protest organisers in the Goldfields probably does not amount to more than 20 people, the attendance at marches and meeting has been high, and the Internet chat sites have hosted thousands of messages to date. Thus, rather than consisting of a permanent body of 
members, these protests have been populated by a loose collective of individuals, who have moved into and out of organisational roles and have contributed different voices over time.

Overall, these protests have been significant in turning what was ostensibly a private financial issue into one of community and nation. It quickly grabbed media attention, starting with the Goldfields, then State, and then national press, and eventually including prime-time national television ${ }^{5}$. Prime Minister John Howard visited Kalgoorlie in April 2001 and proclaimed his belief that investors were not 'tax cheats' but that it was not within his authority to intervene in the Tax Office's actions. The Senate Economics Reference Committee of the Commonwealth of Australia established and conducted an extensive 'Inquiry into mass marketed tax effective schemes and investor protection'. This process began in June 2000 and ended in February 2002, producing three substantial reports detailing evidence received from 899 submissions and numerous public hearings held in five locations (Canberra, Melbourne, Kalgoorlie, Perth and Sydney). Thus, a great deal of public and private time, energy and money has been expended to try and get to the 'bottom' of the issue, both from a legal and a contextual perspective.

\section{Why invest in tax effective schemes? The search for motivations}

Before considering why individuals became involved in social protest against the Tax Office, it is important to understand why they invested in the first place, as, it is argued here, the two strands of questioning are inextricably linked. To begin, there has been much speculation by politicians, the public, the Tax Office and the media about the character and motives of the individuals involved in schemes. Much commentary has either cast affected taxpayers as financially self-interested and greedy system players ('tax cheats') and/or as irrational and misguided simpletons ('tax dupes') (see Murphy \& Sakurai (2001) for further discussion of this argument in tax compliance literature). Although these debates

\footnotetext{
5 This took the form of the Australian Broadcasting Corporation's (ABC) investigative journalism programme called Four Corners airing a programme dedicated to the issue on 18 June 2001 (see http://www.abc.net.au/4corners/stories/s312807.htm).
} 
touch upon some of the key drivers in the social protests, this rather simplistic dichotomy fails to consider the contextual factors of individual's initial investment and subsequent protests.

\section{Understanding the context of investment: Situational and circumstantial factors}

The question of motives for scheme involvement can be argued as having two sides. The first is logistical and practical, with a simple answer to "why did they get involved in schemes?' being 'because they were offered them'. For one, taking advantage of the opportunity to pay less tax in a way promoted as legitimate makes individual's involvement unsurprising. Centre for Tax System Integrity (CTSI) research has shown that $31 \%$ of Australians, responding to a survey on attitudes towards the tax system, reported legally minimising their tax. A further $4 \%$ said they did so through risky ventures and $55 \%$ said they were prepared to 'play around' with their tax situation (Braithwaite et al., 2001). Although in comparison to other post-industrial countries Australians on average see tax fraud as relatively serious, it still remains a 'grey zone of morality' (Evans \& Kelley, 2001). Some interviewees in this research did indeed express the feeling that they were paying 'too much' tax, and were open about looking for ways to minimise their tax payments, with many making comments like 'I don't mind paying tax but ...'

Yet, tax minimisation is not in itself illegal, unlike tax avoidance (although there is a substantial grey area between the two: see Pagone, 2000). This argument was picked up strongly by interviewees. For example:

I think if they're really honest, there's obviously an intention to try and save tax, but to avoid it no way. I mean, these guys - this argument that I had with X, he was going on about tax avoiders and I said to him, 'Hey, hey, these people are working 84 hours a week and they're paying 42 of it to you lot, so who is cheating who here?' He didn't like it, but that's the reality. My husband works. He paid nearly $\$ 1700$ of his last fortnight's pay in tax. So why bother to work 84 hours a week. So I can understand why they would have tried to reduce the amount of tax they were paying, but I don't believe they're trying to avoid it. 
Added to this, the accessibility of schemes made getting involved all too easy. In the same way that many new ideas and practices spread quickly through social networks of colleagues and friends (Rogers, 1995), potential investors heard about the schemes through their own networks. Many reported seeing others reaping the rewards of tax rebates over the years - a new car here, a holiday there - and thus took their cues for the reliability and legitimacy of these schemes from others. In the extract below the interviewee explains how scheme promoters encouraged him to get involved:

They said, 'Look, we've just signed up all these people up in Kalgoorlie.' There's a police department in Kalgoorlie. Well, I knew a couple of coppers in Kalgoorlie and I thought, 'Well, if you signed those boys up ... well, they're not really dills, I'll be all right.' I fell into it, you know.

Most schemes were marketed as legal and sound investments, one endorsed by a QC (Queen's Counsel) and others by local accountants and financial advisers, who, research has shown, have substantial effects on the tax behaviour of clients (Schmidt, 2001). To double-check their legitimacy, 25 investors interviewed sought independent advice from financial planners, accountants, the Australian Securities and Investments Commission (ASIC). A few even reported calling the Tax Office to ask about their legality, saying the Tax Office thus gave them the 'all clear'. Finally, these schemes were sold shrewdly by promoters. They cold-called, canvassed, offered 'spotters fees', utilised networks, made friends and positioned these schemes as something with a limited supply that only a fool would turn down - or 'mate, you'd be the only one who misses out' as one interviewee reported - all to great success. Thus, to ask 'why' here, the answer could easily be 'why not?'

\section{'Stories of motivation': Or, why the truth is not 'out there'}

The second side to the 'why' question is one of personal motivation. Within political and media discussions of the issue this question has been framed as a black and white debate of 'are they tax cheats or were they fooled by wily promoters?' (for example, in the Four Corner's programme). The problem with pursuing this line of questioning is multiple. For one, it assumes that information and knowledge is the only factor here - 'did they know or 
not?' By contrast, although without doubt many tax decisions are carefully planned, many others are often a matter of convenience, opportunity and context (Smith \& Kinsey, 1987). Also, tax decisions are not just the domain of individual rationality but are often family, relational and contextual matters (Smith \& Kinsey, 1987). This means that finding out what one person thinks and feels about tax is not a comprehensive way of understanding the actions and practices of that individual.

Finally, research can never truly uncover individuals' initial motivations for investing in schemes, as they no doubt have become clouded by subsequent events. Even though many interviewees admitted wondering if they had been foolish and inept in their actions, they were reluctant to take the blame for events, as: 'even if being inept isn't one's fault, it still is a less than admirable aspect of selves, one that we might conceal rather than advertise' (Sabini \& Silver, 1997, p. 4).

The selective and creative nature of memory and the psychological need to maintain an integrated sense of the self thus results in past actions becoming shrouded by current concerns and debates. One example can be seen when a much-vilified scheme promoter gave evidence to the Senate Estimates References Committee. Here, he insisted that whilst in the Goldfields potential investors came looking for him, implying he was simply responding to market demands. Investors insist otherwise, stating they were directly targeted. In the absence of documented evidence, research cannot uncover who is right or wrong or the nature of the 'real' events, as this necessitates making a moral judgment about who is more likely to be telling the truth. It also raises the spectre of epistemological debates about the possibility of knowing any form of 'universal truth' in light of increasingly focus on 'local' knowledge (Miller, 2001). Thus, instead of searching for an elusive 'truth', what is interesting are the stories that are currently driving protestors' behaviours, which arguably construct and give form to the moral foundations of their protests. 


\section{'Stories of justification': Future, security and the pride of self-sufficiency}

One strong story to emerge from this research relates to the future security of those in the mining industry. Employment and personal security are without doubt vital components of workers' quality of life, and are reputedly declining in Australia (Kelley \& Evans, 1995). The unwritten rule of 10 years underground being all a person can physically take, coupled with creeping job insecurity, retrenchments and falling wages, lead many to worry about their future and that of their families. For one, there was a fear that state pensions were shrinking to the point of total disappearance, as the two quotes below show:

There will be no such thing as a pension by the time I retire and let alone when you retire - there will be no pensions. So, I mean, how do you live? You've got to have something.

Male: Because my opinion of superannuation is that I reckon they're going to stick it to us there as well. By the time I'm 65, retire, I think they'll change the rules and we'll basically get nothing out of our superannuation. So, we thought well, you know, it's about time that we invested in something ...

Female: Something for ourselves.

Male: And for the kids as well and it was about that time the old knock on the door come.

Thus, a feeling that they had to invest just to secure a liveable future coincided with the availability of these schemes. Few felt that their current superannuation policies provided adequate return and support, a feeling shared by many other Australians (Webster, 1999). In part, this investment urge was driven by signals from the neo-liberal Australian Coalition government that individuals must think about providing for themselves and their families. This argument is framed as being a by-product of an increasingly aged population whose pension demands will push the welfare state to the brink (for example, King et al., 2001). This policy discourse is taking prevalence in other post-industrial countries (for example, Philipps, 2000), and can be seen as part of a broader 'turning inwards' from community as to the self as welfare provider (Everingham, 2001). As one investor pointed out: 
The government are always on to us to do things for yourself so the government isn't supporting you when you're older and retiring. And then the ATO turn around and slug you like this. So, here they are telling us to invest in our future and do the right thing and look after yourself, 'So we're not paying for you when you retire', and all the rest of it and then they do this.

A further issue this raises is that of knowledge. Researchers have argued that neoclassical/liberal economic policies effectively change the 'ground rules' for citizens. Whereas once they had to understand the machinations of the welfare system, they now have to grasp new knowledge and become familiar with economic concepts to keep up their welfare standards (Anderson, 1998). This knowledge is not always easily accessible, understandable or consistent to the average person. Thus, confusion and misguided action can often result.

Investment was also driven by a sense of personal and cultural pride at being a selfsufficient, hard-working Australian, an identity that has great historical and cultural resonance (McCarthy, 1999, Horne, 1964, Schachner, 1990). Interviewees were quick to point out how they had never claimed any state benefits in their lives, that they had always paid their taxes in full and on time, and that they had always tried, economically at least, to 'do the right thing', as the two quotes below suggest:

Because at the end of the day, I mean, we are fully self-sufficient people. We've never, ever been on the dole. We've never lived off the government. My husband and I have always worked. We've always paid our taxes. We've never hidden anything, and for this to happen. We're being punished, you know, and I don't think it's right at all. I feel really strongly about it.

I've served in the military for Australia, I'm an honest hardworking person, I'm married, I've got two kids, I reckon I'm a pretty upstanding sort of citizen.

As a result, they argued their involvement with schemes was far from being a tax dodge, as it was not within their over-all character to take such actions. They saw their paths to security achievable without resorting to illegal practices, a feeling shared by many other 
Australians (for example, Sikora, 2001). Rather, involvement in schemes was first and foremost an investment. As one interviewee put it:

I've been in the mining game for probably nearly nine or ten years now so in that period of time I've paid a lot of tax. Never, ever have I ever had an audit done on me, never had any queries, no dramas at all, just the average, law abiding person that pays their tax. I was at a friend's place one day and there was this representative there. He was going over this scheme called Oracle and at the time, with the information that he was giving us, it sounded like it was a great long-term investment. Like, we weren't meant to make any money out of it, any decent sort of money out of it, between nine to twenty one years. This was like a twenty year plan.

These individuals have a self-identity of being self-reliant individuals who look outside the 'system' for support, as they believed they were being politically signalled and culturally motivated to do. Identity is not merely a personal and/or cognitive construct but a definition of an individual as a social 'object' (Pakulski \& Tranter, 2000). Thus, investors' identities were profoundly compromised by the implications of their amended assessment.

This stems in part from the different models of human action and agency used by the Tax Office and the investors. The rulings of the Tax Office frames individuals' involvement in schemes as operating as isolated, autonomous and fiscal decision-makers. By contrast, investors see it as just one small part of their previous social actions and relations, in which they have tried to be honest and decent (see Helliwell \& Hindess (1999) for a discussion of different epistemological approaches). Thus, they felt they had earned the right to be treated fairly and with discretion, having kept their part to date in a form of undefined 'social contract' between state and individual. To feel that they are labelled as 'tax cheats' appears to them unfounded and inaccurate, coming as a 'moral shock' (Jasper, 1997). This reading of the personal/cultural messages sent out by amended assessments laid the foundations for the protests that followed, which are discussed in greater detail below. 


\section{Can't pay, won't pay: Social protest in the Goldfields}

One of the pragmatic reasons why many have refused to pay their amended assessments is that they cannot afford to. Banks will not provide loans or re-mortgages of property for people with outstanding tax debts, and few have the assets to raise tens of thousands of dollars. Bankruptcy is a bleak option, affecting future financial choices and according to interviews, the settlement offers from the Tax Office were not considered reasonable or affordable. In terms of trying to pay their amended assessment back, one investor commented:

I just don't have it. I can't work any more than I'm working. I work like nearly 14 hours a day, seven days straight and it's just - they're not going to get it out of me. It's simple as that. And if they do try and push me, I can only dribble it back at so much at a time and I'll be paying it off for the rest of my life anyway. So, it's just devastating.

Yet, for many, even if they could pay, they would not, as they feel they have been served with an absolute moral wrong. Many asked why they should pay back money that they did not see, as the vast majority of tax rebates were immediately given to the schemes through their tax agents, leaving on average a couple of thousand dollars 'in hand' per taxpayer. Indeed, any settlement and negotiation was seen as admittance of guilt by some investors. For example:

I've even received a form because, being the lower end of the scale with one licence, I could have signed it, waived all my rights, basically admitted the fact that I was a tax cheat - which I'm not - and then start paying. Well, they're offering four per cent [interest] instead of 12 per cent or 14 whatever it was, and now I've got to just start repaying the money, like - you know, 'Yes, I'm a tax cheat. All right, I'll take the lower percentage rate and start paying you', like. Get stuffed. I'm not going to do it.

Feelings of indignation about assessments relate to both how they were handled as an administrative process by the Tax Office, as well as the implications of assessments for these individuals' futures. To begin with process, all felt that the Tax Office has grossly 
mismanaged the affair through being slow to make rulings over the legality of the schemes and not taking individual circumstances into account when making decisions (see Murphy, 2002, for further discussions of these points).

Added to this was the insult served to their identity, as mentioned above. The apparent cultural pride in being able to be, and being seen to be, a good provider, a hard worker and, in sum, a 'good Australian' was evident, both in this research and in evidence given to the Senate Economics References Committee. Many interviewees talked about themselves as 'average' Australians, and how people like them - the hard workers and high taxpayers were the 'backbone' of the country, funding the tax base that provides nation-wide public services, few of which appear to be returned and re-invested in rural Australia (see Morgan \& Murphy, 2001). Indeed, some protestors and their supporters cast themselves as fighting for justice for average Australians, contrasting their stance on one web-site, with the actions of the Tax Office, which they frame as fundamentally 'unAustralian' (Tax Resolution website). For example:

The sad thing is too, this is affecting the average backbone of Australia. We're not talking about Kerry Packers and stuff here, they don't pay any bloody tax and the average Australian pays the tax and they're the backbone of this country and that's who it's affecting.

As such, interviewees felt justified in categorising themselves as honest Australians who are being served an indefensible wrong. This is not surprising in light of research which shows that taxpayers often view others' compliance and over-all honesty as less than their own (Coleman \& Freeman, 1997). This is also reinforced by media attention given to corporate approaches to tax (non) compliance (see Braithwaite \& Braithwaite, 2001), evident in the fact that the majority of interviews in this research reference the emblematic case of Kerry Packer.

Yet, this view of themselves as honest taxpayers was not only about self-identity, but also about a form of collective identity, both 'imagined' and concrete (for example, Polletta \& Jasper, 2001). Although 'class' is a much-debated concept, it is no doubt highly relevant to contemporary Australia (for example, Kuhn \& O'Lincoln, 1996, McGregor, 1997). In this 
research, interviewees felt their social position as the epitome of the taken-for-granted working class was further insulted and morally eroded by the Tax Office's actions. This experience reinforced perceptions that they are the workers, or 'pawns' or 'little people' and that the 'top end of town' is populated by the privileged few who can break laws to their own desire without having to worry.

The seeming inconsistency or irony of these opinions needs to be noted. By comparative standards to other manual workers in Australia, these individuals are on very high wages and could, economically at least, be considered middle class. Yet, they consider themselves as the archetypes of the working class. To understand this point, it is important to remember the contextual factors of this case study (for example, how the money was earned and the living conditions in the Goldfields). Added to this, research has shown how individuals often position themselves 'in the middle' in terms of class evaluations (Kelley \& Evans, 1995). That is, individuals do not decide which class they belong to through objectively judging their material circumstances. Rather, 'subjective images of equality and consensus among family, friends and co-workers' (Kelley \& Evans, 1995, p. 157) are used to build these pictures. In this sense, protestors are typical in seeing themselves sandwiched between those who strain the welfare system by choosing not to work, and those who gain excess privilege from their social status. This latter attitude is somewhat supported in the Australian population at large, where many feel big businesses, their managers, as well as senior barristers and judges pay less than their fair share of tax (see Braithwaite et al., 2001).

As well as personal and collective identity, many investors talked about the alleged shortsighted logic of the amended assessments. They felt the Tax Office's actions amounted to essentially financially ruining families to collect revenue that will then have to be spent on their welfare and future support when they are destitute, as the quote below shows:

[It's] just so, so wrong. Here's 58000 Australians - and let's take out the couple of percent who are maybe tax cheats - so let's say there's even 50000 people plus their families who, in good faith, invested in Australia and for that they're going to 
lose everything. I mean, yeah, there's some that can pay back. But then there's the others who will lose everything, and then there's the others who have taken their lives.

This also shows how many did not see the actions of the Tax Office as 'black-boxed' away from other state agencies. In short, Australian taxation officers know all too well the boundaries of their institutional ambit. By contrast, many citizens do not see these boundaries and instead lump together all the actions of state agencies as 'the government'. Thus, they cannot understand why 'the government' would choose to take with one hand what it will then have to offer back with another.

Others dwelt on how it had destroyed lives and marriages. The extract below concerns a meeting that took place between some investors and community workers in Kalgoorlie, local politicians and individuals from the Tax Office.

So we got onto a discussion of 'a line in the sand'. A couple of people in the ATO and one of the politicians in attendance had this huge issue that if they did that, there might be some people that actually tried to rort the system and might actually get away with it. And that really pissed me off because I thought, you know, you're prepared to let people take their own lives provided a few people don't actually manage to cheat the system.

This scenario was deemed so outrageously lacking in commonsense that protestors withdrew from taking part in any negotiation process with the Tax Office, feeling legitimised in their moral position of refusing to pay and publicly declaring as such. As one interviewee put it:

Your legitimate tax cheats, you go after them, they deserve it but as far as we're concerned, we are not tax cheats. We did nothing wrong. You know, we tried to do something right and we've been burnt by it.

The feelings of being judged by others as tax cheats for some only added strength to their feelings of indignation. For example: 
I went to see $X$ about it, and I was disgusted with him. He basically said to me that anybody that invests in that kind of investment is greedy. So, what he's saying is that my husband is greedy. And I looked at him and I thought, how can you say that? You know, that's not right.

This created a feeling that investors were being stigmatised, not only in their own community but also across Australia.

\section{Why the Goldfields?}

Although thousands of people across Australia have been involved in the schemes, some of the strongest voices of protest to emerge have been from the Goldfields. Why is this? For one, there is the simple fact that this region was targeted more aggressively than any other spatially proximate collection of individuals anywhere else in Australia. Also, the nature of how people got involved in schemes - through work, friends and family - meant that individuals quickly knew of others receiving amended assessments. Even though (and maybe because) the Goldfields are geographically isolated, the communities are small and highly networked. Thus, the dense networks that had fuelled high numbers of individuals investing in the first place later fuelled the protests. As one interviewee put it:

And I think you have to understand how people receive information in the mining industry. It is through talking to one another, they talk shop. They work 12 hours a day, they work 84 hours a week, they often work underground. They have small peer group relationships.

These small peer groups meant the word was quick to spread. Even though the actual number of people involved does not appear to exceed one thousand, the prevalence of networks as the main sources of communication makes it feel like everyone is somehow involved. And with so many individuals' friends and family touched by amended assessments, private anger became collective indignation, adding strength to the feeling that somehow, their lives and communities were being assaulted. As people began to talk about their experiences and realise how many others were involved, the protest network 
also doubled as a support network, which enabled those affected to share and cope with this major negative life event (see Finkenauer \& Rime, 1998).

It seems therefore that there was a critical mass of people in the Goldfields - and a key few who were willing to take initial moves of pulling the community together - who shared similar feelings of outrage and who were having similar distressing experiences. This culmination of collectivity, of 'not being alone' and conclusions that if they could not pay, they had nothing to lose in protesting, created a moral determination to fight the Tax Office and to not feel ashamed of what had happened to them:

You see, there's a lot of us are alike. We don't give a shit, we're going to scream all the way, you know. And then there's the other ones that go, 'I don't want to talk about it, I'm so ashamed, I feel like a fool,' you know, 'I don't want anyone to know what my situation is.' Well, I'm like, 'Stuff it. It's not just me.' There's so many other people in this one town and various towns around us. Like, Kambalda and Menzies and Leonora and Leinster and all that. There's just so many people so I'm not ashamed. I didn't do anything wrong.

Added to this, there was a regional identity that was evoked through protests. Many felt that the Goldfields was an isolated area with particular needs and people, often ignored and misunderstood and passed judgment on by other Australians:

... because in the eastern States they think, 'Oh, tax cheats, let them go'. They don't look at - the people involved are ordinary people, you know, husbands and wives and are people like myself who are involved in the community, and then go and suicide and stuff like that. We just - it's traumatic. I sit here and I listen to people talking about suicide and bankruptcy and stuff and like, you just feel for them.

The reported tough life of the Goldfields was suggested to give rise to 'tough' people, who had their own way of dealing with issues. One interviewee called this a 'Kalgoorlie approach' and another stated that the area was run on 'Kalgoorlie rules'. As one interviewee put it:

It's not in our nature to lay down and die. We're scrappers, I'm afraid, to use a pretty sort of ordinary word, we're scrappers. I'll dig my heels in. 
Thus these experiences helped to re/create a regional identity that saw Goldfields inhabitants as different, misunderstood and resilient. This is not at odds with their views of themselves as Australians, as Yuval-Davis has pointed out: 'People's membership in a state, their rights and responsibilities, are mediated by their membership in other collectivities and polities, sub-, cross- and supra-state' (Yuval-Davis, 1999, p. 131). This identity thus did not diminish but rather added to the strength of their convictions.

\section{The cultural politics of social protest against the Tax Office}

One community worker interviewed argued that protestors' anger is misplaced. Instead of feeling angry with the Tax Office, it is the scheme promoters who are the real culprits. There is some merit in this point. Those involved in schemes still trading cannot understand why the Tax Office could call their investment business a 'sham'. However, those involved with companies that have since ceased trading are quicker to point the finger of blame at promoters (that is, they now feel that their business investment was not legitimate). Added to this, the Internet sites and other forms of communication do appear to be spaces where rumour and counter-rumour, often unsubstantiated, are aired, thus adding to the justifications of investors and their feelings of persecution which are not always with grounding.

Yet, rather than simply dismiss protests as whipped-up hysteria, or that protestors are being lead by the nose through the fighting funds or other interest groups, these protests can tell us something about issues affecting governance in Australia. One argument focuses on the contrasting epistemological stances of the Tax Office and protestors. That is, administrative governance decisions do not just reside in the individual and social domains of bureaucratic rationality, echoing the 'perspective of the state' (Taylor, 1998). Instead, regulatory rulings send out symbolic and cultural messages, blurring and challenging the existence of supposed boundaries between private and private spheres of governance (for example, Della Porta \& Diani, 1999, Lemke, 2001). Whilst agencies may discursively focus on law and revenue, the implications and messages of these discourses, both material 
and symbolic, are deeply affective to individuals in terms of their own identities, their social positions and their prospective futures as citizens.

This is because economy and culture are not separate spheres of cognition or practice. Rather: 'economic logics work in and through a whole set of cultural processes which give everyday sense to the outcomes of society' (Jacobs, 1999, p. 13). Thus, the idea that Goldfields protests are about money and taxation, plain and simple, is untenable in light of investors' concerns over their identity, security, faith and the future. This merging of these protest drivers defies any attempt to theoretically black-box social protests and their actors into categories such as self and other focussed, material and post-material. Rather, they exist in the fuzzy space of being both at the same time (Goodwin et al., 2001).

And as such tax becomes a site of 'cultural politics'. This is the idea that 'all social life must be seen as potentially political, where politics is the contestation of relations of power' (Nash, 2001, p. 77). Here, the power struggles in the form of protests are both material (that is, not paying tax bill) and symbolic (public protests, fighting funds). Thus, what was once purely personal (that is, tax) now becomes an issue for debate and contestation.

What is also significant is how protesters have withdrawn from previously cooperative systems of economic governance. This suggests they signal a potential opening of new cleavages or points of questioning in Australia today. As mentioned earlier in this paper, Melucci (1989) argues that citizenship struggles are not over. Rather the different dimensions of conflict have taken on new shapes. In this light tax has (re) emerged as a dimension of conflict that challenges the logic of state or institutional regulatory practices. Protestors are collectively impelling a more humanistic approach to social management through resisting the 'bureaucratisation' of their lives (Buechler, 1995). And as such they open up new possibilities for political contestation (for example, Nash, 2000). Or as Melucci (1989, p. 1) framed it: 
Social movements [also] publicize grievances and uncertainties about everyday life, as well as challenge the less visible power relationships crystallized in its shared conventions and sense of normalcy.

Thus, the normalcy of deferring to law, or feeling shame for alleged wrong-doing, have been made redundant by the protest in the Goldfields. Here, the cultural politics of tax has started to uncover issues of power relations that, as Melucci suggests, remain 'less visible' in everyday life. What began as amended assessments in the post to a few thousand people became a public challenge to the legitimacy of a powerful government agency. This challenge was based on moral justifications of being a good Australian who has been served a wrong by the very system that they, and other workers like them, are financing, and which they believe is meant to be looking after their welfare.

\section{Concluding remarks}

I spoke to that many guys on the mine sites that say, 'Up their arse, they are not getting a red cent out of me, I will go on the dole for the next three years, I will do whatever it takes to not give them a red cent'. And that's their attitude.

Despite the concessions offered by the Tax Office, many investors state they will only feel vindicated by a 'line in the sand'. Indeed, it seems that only the Federal Court ruling on schemes will elicit some individuals' willingness to now think about settling their debts or going bankrupt (Buffini \& Fabro, 2002). Attempts to draw or force these taxpayers back into cooperation and recognition of the authority of the Tax Office, no matter how reasonable they may appear to others, will be a struggle, to say the least. In this research, investors talked about actively and purposefully disengaging from the tax system now and into the future, such as paying cash for services wherever possible. Others commented that they would rather go on the dole than keep working the rest of their lives just to pay the Tax Office, as the quote at the beginning of this section shows. Indeed, the goal of giving 'those bastards' as little money as possible seems to have been transformed into a moral mission by many (see also Murphy, 2002). Although fiscally this position is detrimental to Australian-wide public welfare, economic arguments fall on deaf ears when put to those affected by amended assessments. 
Does this suggest that these protests are an aberration, an unfortunate alignment of events, personalities and social trends? Perhaps, but there are also important lessons to be learnt. One signals the implications of these protests for issues of governance in Australia, in particular in relation to tax. In one sense, these protests are defensive and reactive, focussing on this one specific issue they want resolved for personal benefit. This suggests that protestors are 'nomads of the present' (Melucci, 1989). Melucci coined this phrase to help explain why much social protest today appears to lack utopian visions as end goals compared to, for example, socialism or deep ecology. Rather, protest is often issue focussed, looking for the resolution of one problem, and often nothing more beyond that. In this case study, the investors want their 'line in the sand'. If this were granted, no doubt the vast majority would cease protest and political activities.

However, these protests are also productive. There is a tearing open of the prevailing divide between culture and economy held so central to state modus operandi. This is not a unique event but rather marks the constant creation and re-creation of how citizens relate to the state. Here, there is a new understanding of what the 'social contract' should and does mean. Individuals are not just bowing down to others interpretations and message about who they are and what their actions means. Instead, the age-old fight for identity and security continues, but in different forms. And as such, institutions of governance cannot afford to 'stand-still' in their conceptualisations of who and how to govern.

For one, many would argue that the adoption of the discourses of fairness, individuality and openness - such as in the Taxpayers' Charter - reflect this willingness to engage with the cultural aspects of citizenry. Yet, the adoption of the contestable and personally constructed concepts such as 'fairness' does open the way for calls of duplicity, especially if institutions are seen to not put concepts through into practice. In the eyes of citizens, these failures are potentially devastating, as this case study shows. Researchers have pointed out the need to find creative, adaptable and flexible regulatory enforcement solutions (Tenbrunsel, 1999, Tomkins et al., 2001).

This case study bears those assertions out empirically. Although there is no doubt more qualitative research is needed into how contemporary Australians view their regulatory 
institutions, these protests suggest that new spaces of contestation - or a new defiance (Braithwaite forthcoming) - face institutions when their actions evoke and seemingly betray debates about citizenship and governance. In these circumstances, values underpinning notions of paying tax as the 'right thing' to do disappears, and the Tax Office's 'benign big gun' (Ayres \& Braithwaite, 1992) is suddenly out of bullets. Even if the individuals in this case study are beyond 'free and frank' discussions needed to find adaptive regulatory solutions (Braithwaite, forthcoming), institutions should not shy away from thinking about how those conversations might sound in the future. One first step might be to acknowledge protestors' claims as legitimate. This does not mean conceding on points of law, only understanding that the contexts and outcomes of involvement with schemes reach far and beyond the ambit of law and economy. Perhaps then the cultural politics of governance will become the focus of discussion that this case study suggests as imperative. 


\section{REFERENCES}

Anderson, M. (1998). Neoclassical economics and the Australian community: How does the public arrange economic logic? Melbourne Institute Working Paper No. 25/98, Melbourne Institute of Applied Economic and Social Research. The University of Melbourne.

Ayres, I., \& Braithwaite, J. (1992). Responsive regulation: Transcending the deregulation debate. Oxford University Press.

Blainey, G. (1993). The golden mile. Allen and Unwin.

Blumenthal, M., Christian, C., \& Slemrod, J. (2001). Do normative appeals affect tax compliance? Evidence from a controlled experiment in Minnesota. National Tax Journal, $54(1), 125-138$.

Braithwaite, V. (forthcoming) The new defiance: Challenging integrity and legitimacy. Ashgate.

Braithwaite, V., \& Braithwaite, J. (2001). An evolving compliance model for tax enforcement. In N. Shover, \& J. P. Wright (Eds.), Crimes of privilege: Readings in whitecollar crime. Oxford University Press.

Braithwaite, V., Reinhart, M., Mearns, M., \& Graham, R. (2001). Preliminary findings from the Community Hopes, Fears and Actions Survey. Centre for Tax System Integrity Working Paper No. 3. Canberra: Australian National University.

Buechler, S. M. (1995). New social movement theories. The Sociological Quarterly, 36(3), 441-464.

Buffini, F. (2002). It's 'bankruptcy for thousands'. The Australian Financial Review, Tuesday 19 March, 9. 
Buffini, F., \& Fabro, A. (2002). 40,000 hit in tax plan loss. The Australian Financial Review, Tuesday 19 March, 1 and 9.

Chidlow, G. (1998). Men, their families and work in rural and remote regions: The wider implications. Forum on Men and Family Relationship, Hyatt Hotel, Canberra, 9 - 11 June, http://law.gov.au/aghome/commaff/lafs/frsp/mensforum/Welcome.html.

Christensen, W. J. K. (1979). Aborigines of Kalgoorlie-Boulder. In R. M. Berndt, \& C. H. Berndt (Eds.), Aborigines of the west. UWA Press.

Coleman, C., \& Freeman, L. (1997). Cultural foundations of taxpayer attitudes to voluntary compliance. Australian Tax Reform, 13, 311-336.

Commonwealth Ombudsman. (2001). Annual report. Commonwealth Ombudsman. Commonwealth of Australia.

Della Porta, D., \& Diani, M. (1999). Social movements: An introduction. Blackwell Publishers.

Evans, M. D. R., \& Kelley, J. (2001). Are tax cheating and welfare fraud? Public opinion in 29 nations. Australian Social Monitor, 3(4), 157-179.

Everingham, C. (2001). Reconstituting community: Social justice, social order and the politics of community. Australian Journal of Social Issues, 36(2), 105-122.

Finkenauer, C., \& Rime, B. (1998). Socially shared emotional experiences vs. emotional experiences kept secret: Differential characteristics and consequences. Journal of Social and Clinical Psychology, 17(3), 295-318.

Goodwin, J., Jasper, J. M., \& Polletta, F. (2001). Passionate politics: Emotions and social movements. In J. Goodwin, J. M. Jasper, \& F. Polletta (Eds.), Passionate politics: Emotions and social movements. The University of Chicago Press. 
Harris, E., Montefiore, D., \& Ferguson, K. (2001). Goldfields community legal centre: Survey summary into tax effective schemes. Kalgoorlie, Australia.

Helliwell, C., \& Hindess, B. (1999). 'Culture', 'society' and the figure of man. History of the Human Sciences, 12(4), 1-20.

Horne, D. (1964). The lucky country: Australia in the sixties. Penguin Books.

Howitt, R. (1990). All they get is dust: Aborigines, mining and regional restructuring in Western Australia's Eastern Goldfields. Research Paper 5 for the Royal Commission Into Aboriginal Deaths in Custody.

Hudson, W., \& Kane, J. (2000). Rethinking Australian citizenship. In W. Hudson, \& J. Kane (Eds.), Rethinking Australian citizenship. Cambridge University Press.

Jacobs, J. M. (1999). The labour of cultural geography. In E. Stratford (Ed.), Australian cultural geographies. Oxford University Press.

Jasper, J. M. (1997). The art of moral protest. The University of Chicago Press: Chicago and London.

Kelley, J., \& Evans, M. D. R. (1995). Class and conflict in six western nations. American Sociological Review, 60(2), 157-179.

King, A., Walker, A., \& Harding, A. (2001). Perspectives on Australian retirement incomes. The Australian Economic Review, 34(2), 155-169.

Kuhn, R., \& O'Lincoln, T. (1996). Class \& class conflict in Australia. In R. Kuhn, \& T. O'Lincoln (Eds.), Class \& class conflict in Australia. Melbourne: Longman, Australia.

Laurence, M. (2001). Tax revolt. Business Review Weekly, 9 March, 56-63. 
Lemke, T. (2001). 'The birth of bio-politics': Michel Foucault's lecture at the College de France on neo-liberal governmentality. Economy and Society, 30(2), 190-207.

McCarthy, W. (1999). A fair go: Portraits of the Australain dream. Edgecliff, NSW.

McGregor, C. (1997). Class in Australia. New York, N.Y: Penguin Books.

Melucci, A. (1989). Nomads of the present: Social movements and individual needs in contemporary society. Hutchinson Radius.

Miller, H. T. (2001). The epistemic community. Administration and Society, 32(6), 668685.

Morgan, S., \& Murphy, K. (2001). The 'Other Nation'? Understanding rural taxpayers attitudes towards the Australian Tax System. Centre for Tax System Integrity Working Paper No. 26. Canberra: Australian National University.

Murphy, K. (2002). Procedural justice and the Australian Taxation Office: A study of tax scheme investors. Centre for Tax System Integrity Working Paper No. 35. Canberra: Australian National University.

Murphy, K., \& Sakurai, Y. (2001). Aggressive Tax Planning: Differentiating those playing the game from those who don't. Centre for Tax System Integrity Working Paper No. 25. Canberra: Australian National University.

Nash, K. (2000). Contemporary political sociology: Globalization, politics and power. Blackwell Publishers.

Nash, K. (2001). The 'cultural turn' in social theory: Towards a theory of cultural politics. Sociology, 35(1), 77-92. 
Nichols, B. (2001). Deaths continue in West Australian mines. World Socialist Web Site, 6 June.

Pagone, G. T. (2000). Tax planning or tax avoidance. Australian Tax Review, 29, 96-119.

Pakulski, J., \& Tranter, B. (2000). Civic, national and denizen identity in Australia. Journal of Sociology, 36(2), 205-222.

Panelli, R. (2001). Narratives of community and change in a contemporary rural setting: The case of Duaringa, Queensland. Australian Geographical Studies, 39(2), 156-166.

Patterson Market Research. (1999). Living in the regions: The views of Western Australians. Government of Western Australia.

Philipps, L. (2000). Taxing the market citizen: Fiscal policy and inequality in an age of privitization. Law and Contemporary Problems, 111.

Polletta, F., \& Jasper, J. M. (2001). Collective identity and social movements. Annual Review of Sociology, 27(1), 283-299.

Probyn, E. (1997). Mc-Identities: Food and the familial citizen. In P. Patton, \& D. AustinBroos (Eds.), Transformations in Australian society. Research Institute for Humanities and Social Sciences: University of Sydney.

Rogers, E. M. (1995). Diffusion of innovations. Free Press.

Sabini, J., \& Silver, M. (1997). In defence of shame: Shame in the context of guilt and embarrassment. Journal for the Theory of Social Behaviour, 27(1), 1-15.

Schachner, R. (1990). In J. Lack, \& F. Ohles, \& J. Tampke (Eds.), The workers' paradise?: Robert Schachner's letters from Australia, 1906-07. Parkville, Vic: History Dept., University of Melbourne. 
Schmidt, D. R. (2001). The prospects of taxpayer agreement with aggressive tax advice. Journal of Economic Psychology, 22, 157-172.

Senate Economics References Committee. (2000). Inquiry into mass marketed tax effective schemes and investor protection. Submission 845 by the Australian Taxation Office, Australian Taxation Office.

Senate Economics References Committee. (2001a). Inquiry into mass marketed tax effective schemes and investor protection: Interim report. Parliament of the Commonwealth of Australia.

Senate Economics References Committee. (2001b). Inquiry into mass marketed tax effective schemes and investor protection. Second report: A recommended resolution and settlement. Parliament of the Commonwealth of Australia.

Sikora, J. (2001). Is corruption necessary for upward mobility? Perceptions from 26 nations in 1999/2000. Australian Social Monitor, 4(4).

Smith, K. W., \& Kinsey, K. A. (1987). Understanding taxpaying behavior: A conceptual framework with implications for research. Law and Society Review, 21(4), 659-663.

Stimson, R. (2001). Dividing societies: The socio-political spatial implications of restructuring in Australia. Australian Geographical Studies, 39(2), 198-216.

Strauss, A. L. (1987). Qualitative analysis for social scientists. Cambridge University Press.

Taylor, D. (1998). Social identity and social policy: Engagement with postmodern theory. Journal of Social Policy, 27(3), 329-350.

Tenbrunsel, A. E. (1999). Trust as an obstacle in environmental-economic disputes, American Behavioral Scientist, 42(8), 1350-1367. 
Tomkins, C., Packman, C., Russell, S., \& Colville, I. (2001). Managing tax regimes: A call for research. Public Administration, 79(3), 751-758.

Turner, B. S. (2001). The erosion of citizenship. British Journal of Sociology, 52(2), 189209.

Webster, E. (1999). Superannuation: Why choose it? Australian Social Monitor, 2(1).

Yuval-Davis, N. (1999). The 'multi-layered' citizen. International Feminist Journal of Politics, 1(1), 119-136. 


\section{THE CENTRE FOR TAX SYSTEM INTEGRITY WORKING PAPERS}

No. 1. Braithwaite, V., \& Reinhart, M. The Taxpayers' Charter: Does the Australian Taxation Office comply and who benefits? December 2000.

No. 2. Braithwaite, V. The Community Hopes, Fears and Actions Survey: Goals and Measures. March 2001.

No. 3. Braithwaite, V., Reinhart, M., Mearns, M., \& Graham, R. Preliminary findings from the Community Hopes, Fears and Actions Survey. April 2001.

No. 4. Mearns, M., \& Braithwaite, V. The Community Hopes, Fears and Actions Survey: Survey method, sample representativeness and data quality. April 2001.

No. 5. Sakurai, Y., \& Braithwaite, V. Taxpayers' perceptions of the ideal tax adviser: Playing safe or saving dollars? May 2001.

No. 6. Wenzel, M. The impact of outcome orientation and justice concerns on tax compliance: The role of taxpayers' identity. June 2001.

No. 7. Wenzel, M. Misperceptions of social norms about tax compliance (1): A prestudy. June 2001.

No. 8. Wenzel, M. Misperceptions of social norms about tax compliance (2): A field-experiment. June 2001.

No. 9. Taylor, N. Taxpayers who complain about paying tax: What differentiates those who complain from those who don't? June 2001.

No. 10. Wenzel, M. Principles of procedural fairness in reminder letters and awareness of entitlements: A prestudy. June 2001.

No. 11. Taylor, N., \& Wenzel, M. The effects of different letter styles on reported rental income and rental deductions: An experimental approach. July 2001.

No. 12. Williams, R. Prosecuting non-lodgers: To persuade or punish? July 2001.

No. 13. Braithwaite, V. Tensions between the citizen taxpaying role and compliance practices. Forthcoming

No. 14. Taylor, N. Understanding taxpayer attitudes through understanding taxpayer identities. July 2001. 
No. 15. Shover, N., Job, J., \& Carroll, A. Organisational capacity for responsive regulation. August 2001.

No. 16. Tyler, T. R. Trust and law-abidingness: A proactive model of social regulation. August 2001.

No. 17. Genser, B. Corporate income taxation in the European Union: Current state and perspectives. August 2001.

No. 18. McBarnet, D. When compliance is not the solution but the problem: From changes in law to changes in attitude. August 2001.

No. 19. Schneider, F., Braithwaite, V., \& Reinhart, M. Individual behaviour in Australia's shadow economy: Facts, empirical findings and some mysteries. September 2001.

No. 20. Taylor, N., \& Wenzel, M. Comparing rental income and rental deductions for electronic versus paper lodgers: A follow-up investigation. November 2001.

No. 21. Braithwaite, J. Through the eyes of the advisers: A fresh look at tax compliance of high wealth individuals. September 2001.

No. 22. Braithwaite, J., Pittelkow, Y., \& Williams, R. Tax Compliance by the very wealthy: Red flags of risk. September 2001.

No. 23. Braithwaite, J., \& Williams, R. Meta risk management and tax system integrity. October 2001.

No. 24. Braithwaite, J., \& Wirth, A. Towards a framework for large business tax compliance. November 2001.

No. 25. Murphy, K., \& Sakurai, Y. Aggressive Tax Planning: Differentiating those playing the game from those who don't? October 2001.

No. 26. Morgan, S., \& Murphy, K. The 'Other Nation': Understanding rural taxpayers' attitudes toward the Australian tax system. December 2001

No. 27. Ahmed, E., \& Sakurai, Y. Small business individuals: What do we know and what do we need to know? December 2001.

No. 28. Hobson, K. Championing the compliance model: From common sense to common action. December 2001.

No. 29. Smart, M. The Under-30 taxpayer: Different from the rest? Forthcoming. 
No. 30. Job, J., \& Honaker, D. Short-term experience with responsive regulation in the Australian Taxation Office. May 2002.

No. 31. Frey, B. A constitution for knaves crowds out civic virtues. June 2002.

No. 32. Feld, L., \& Frey, B. Trust breeds trust: How taxpayers are treated. June 2002.

No. 33. Wenzel, M. An analysis of norm processes in tax compliance. July 2002.

No. 34. Wenzel, M. The social side of sanctions: Personal and social norms as moderators of deterrence. October 2002.

No. 35. Murphy, K. Procedural justice and the Australian Taxation Office: A study of tax scheme investors. October 2002.

No. 36. Hobson, K. Financing Australia: A 'post-modern' approach to tax compliance and tax research. August 2002.

No. 37. Hobson, K. 'Say no to the ATO': The cultural politics of protest against the Australian Tax Office. December 2002. 